\title{
EAl Endorsed Transactions

\section{Empirical Study of Entrepreneurial Attitude and Entrepreneurial Intentions towards Entrepreneurship among PG Diploma Students in Chennai District}

\author{
J. Jose Prahbu \\ Independent Researcher and Visiting Professor, Management and Engineering Colleges (Freelance), Tamil Nadu, INDIA
}

\begin{abstract}
The present short article is an attempt that has been made to examine the students' attitude and intentions in the direction of Entrepreneurship in Chennai City. Entrepreneurial Personality type consists of the human features, capabilities, motives, mindsets, and also worths that form the individual person's experiences as well as actions. Entrepreneurial intentions are likewise taken into consideration as personal alignments which might cause venture developments. Hence, personality traits create the psychological and also behavioral procedures of people. Entrepreneurship is area relevance has elevated multifold over the last couple of decades around the world and also in the last number of years in India. Entrepreneurship has actually come to be a daily buzzword. Policymakers, economists, academics and even college students are discussing it.
\end{abstract}

Keywords: Entrepreneurial Attitude, Entrepreneurial Intention, Entrepreneurial Personality, Educational Research, Learning and Teaching

Received on 05 April 2020, accepted on 03 February 2021, published on 05 February 2021

Copyright (C) 2021 J. Jose Prahbu et al., licensed to EAI. This is an open access article distributed under the terms of the Creative Commons Attribution licence (http://creativecommons.org/licenses/by/3.0/), which permits unlimited use, distribution and reproduction in any medium so long as the original work is properly cited.

doi: 10.4108/eai.5-2-2021.168651

*Corresponding author. Email: Drjose999@gmail.com 


\section{Introduction}

Students of today's generation are the future entrepreneurs of the country. Entrepreneurship is viewed to bring economic welfare and also might add dramatically in the nation's future wealth. Lots of college graduates are incapable to find work properly with the degree they finished. Entrepreneurship education has actually been acknowledged by several companies and also the government as an appealing method to boost the work insertion of young people as well as at the very same time, contribute to society and also economic welfare. Entrepreneurship produces jobs

that subsequently generate many more opportunities. Entrepreneurship is classic. From the extremely young to very old, people are beginning a brand-new company at a quick price. One source of the unexpected rise of new entrepreneurs is the present fad of experts that leave their firms to begin putting their very own businesses. Today, youngsters are exhibiting great intention in establishing of a business. It is critical to determine these youngsters early as well as to grow their entrepreneurial energy.

Entrepreneurship is the growth of a company from the ground upcoming up with a suggestion and also transforming it right into a profitable organization. But while the interpretation of entrepreneurship might be simple, its execution is a lot more difficult. DíazGarcía, M. C., \& Jiménez-Moreno, J. (2010) "Entrepreneurship is the journey of opportunity expedition and risk administration to develop value commercial and also or socially excellent. Gottlieb said that a business owner is somebody that can take any type of concept, whether it be an item and/or service, and also have the capability, will as well as courage to take the extreme danger to do whatever it requires to transform that principle into reality and not only bring it to market, yet make it a feasible item and/or service that individuals desire or need.

A business owner but there is specific features that most effective entrepreneurs possess, Capacity to intend

- Communication Abilities

- Advertising abilities

- Basic Monitoring Abilities

- Interpersonal Skills

- Leadership Abilities

Kristiansen, S., \& Indarti, N. (2004) they are the risktaker and also it is the prime objective that ought to be established in the students. Students are the forth comer that can become an entrepreneur Entrepreneurship plays an important function in the surge and also the success of a country by growing the pupils and young business owners with advancement and business capability, which improves their competitiveness of work and also advancement under the scenario of financing dilemma. Successful business owners are those which always gain from their failings; which constantly attempted to solve troubles; tried to strengthen their weaknesses as well as ensure that this is what we in fact want.

\section{Key Attitudes of Entrepreneurs}

Right here are 5 key perspectives every business owner has to dominate in order to run a prosperous organization venture:

\section{ENTHUSIASM}


Krueger Jr, N. F., et al (2000) Business owners ought to be enthusiastic regarding their ideas, objectives and, of course, their business. This passion is what drives them to do what they do. Some entrepreneurs love the experience and excitement of creating something brand-new, and when it is developed they weary as well as proceed to something else. Various other entrepreneurs really feel enthusiastic regarding the product they are constructing or the feeling of accomplishment they really feel because they recognize they are helping other individuals, aiding animals or helping the planet. Whatever drives a specific to attempt to prosper is where his/her passion lies, which enthusiasm is indispensable to business life?

\section{BRAVERY}

Zampetakis, L. A., et al (2009) Business owners, like every person else, feel concerned. They are scared that they won't be successful or frightened a wellconceived concept cannot be executed. They do not, however, allow these concerns of failing to specify them. They are enduring. They learn from failing. They utilize their worry of falling short to press themselves to function tougher and also to aim to deal with the errors that might have created them to fall short. Many business owners need several attempts to create an effective firm. It is bravery that drives them to go after success.

\section{ADAPTABILITY}

Bucar, B., et al (2003) Entrepreneurs experience obstacles. There are obstacles to get rid of any type of journey. Not every person takes care of change or frustration well. Nevertheless, business owners have to have a versatile frame of mind so they can modify a course that appears to be headed towards failing. Versatile business owners should understand that they may need to customize the course toward their wellknown objective, and even possibly modify that wellestablished goal, in order to reach it efficiently.

\section{SOLID WORK PRINCIPLES}

Nabi, G.,et al (2008) It is hard to start from the ground up and end up being a successful company owner. Lots of hrs of effort, irritation, imagination as well as guidance are poured into a brand-new venture. If you are not ready to stand up and strive every day, probably 7 days a week, then just how can you anticipate success? No effective service is developed promptly, conveniently or without quarrel. Business owners do not work a basic 10-6 day, nor do they log 38-hour workweeks. They are constantly functioning-establishing originalities, producing new items, designing brand-new procedures, working with wise and also skilled individuals. Entrepreneurs encourage themselves and also continually look onward.

\section{STABILITY}

Bosma, N., \& Schutjens, V. (2009) Entrepreneurs should have the ability to reveal others they are sincere and honest. Despite the kind of business, they hope to establish, associate, suppliers, consumers, and financiers must trust them. There is no other way around this-- business owners have to be relied on, as well as trust fund needs to be earned. The most effective business idea in the world will likely stop working if an undependable individual goes to the helm. Distributors require understanding that repayments for items they have delivered will certainly arrive on time. Clients need to recognize that whatever 
service or product they have ordered will be delivered as assured. Associates require recognizing that they are a valued component of the company's success. Capitalists require understanding that the firm has to possible to grow.

Trevelyan, R. (2009) Unemployment has actually grown a new plant of the company owners. This increase of entrepreneurship suggests the times as those that are having trouble locating a job are currently producing their very own. Perhaps this is why, according to a post on CNN.com, 79 percent of American companies have no staff members apart from the owner. However entrepreneurship is far more than beginning a business, being your very own boss, transforming ideas into revenue; or being socially accountable, and so forth. Entrepreneurship is a perspective; it represents exactly how you think and act. It's not simply a business term anymore; for more and more people, entrepreneurship is a way of life. Despite whether you are a leader in your own service or in the corporate globe, the 21st-century work environment demands we embrace a business perspective that is clear, versatile, credible, and also versatile; and we should equip other people to do the same.

\section{Literature Review}

Bosma, N., \& Schutjens, V. (2011) studied about differences in the entrepreneurial tasks and business attitudes are significant and persistent throughout nations as well as regions. However, researches on entrepreneurship that include areas and nations at the same time are doing not have. This paper discusses both nationwide as well as regional differences in entrepreneurial perspective and task for 127 regions in 17 European nations, based on International
Entrepreneurship Screen data. We expose the significance of institutional aspects and economic and also demographic credit to variations in regional business attitude and also activity. Our findings aim at the significance of comparing parts of business attitudes, i.e. fear of failure in beginning service, understandings on start-up chances and also selfassessment of individual abilities to begin a company. We locate various factors of these parts, suggesting that they reflect different aspects of the business mindset. In clarifying local prevalence prices of stages in business activity (incipient, infant business, established organization) we discover substantial contributions of business mindset elements. Urban regions, as well as areas with high degrees of close-by start-up examples, reveal fairly high rates of earlystage entrepreneurship. A lot of start- up procedures don't prevent early-stage entrepreneurship.

Beugelsdijk, S., \& Noorderhaven, N. (2004) studied about in the literary works elements like business capability, regional cutting-edge capacity, and entrepreneurial human funding are stressed in discussing the economic success of areas. Making Use of the European values Researches dataset on standards as well as values in 54 European areas, we distinguish values that characterize self-employed, which enables us to build a local accumulation that mirrors the average rating on the entrepreneurial mindset. We reveal that areas vary in entrepreneurial attitude, which a high score on business attributes is associated with a high rate of regional economic development. By doing this we empirically develop the web link between society and economic situation at the regional degree.

Chen, Y. F., \& Lai, M. C. (2010) researched about a 
design of perspective towards entrepreneurship and the aspects affecting this were examined with students in the business department at a technical institution of higher learning in Taiwan. Personality traits were taken on as the independent variable, ecological cognition as the intervening variable, as well as perspective towards entrepreneurship as the reliant variable. Study sets of questions $(1,085)$ were distributed to students of whom 881 were returned, and also 792 of these were valid. The reactions were examined making use of step-by-step regression as well as LISREL. Outcomes suggested that student mindset toward entrepreneurship was affected by environmental cognition and also personality type, which indirectly impacted mindset towards entrepreneurship.

Turker, D., \& Selcuk, S. S. (2009) examined about fostering entrepreneurship requires a two-fold policy that should focus on both the current situation as well as the future prospect of entrepreneurship. Although lots of scholars and policy makers commit their interest to the initial emphases of concern, it is equally important to draw up the future context of entrepreneurship. The purpose of this paper is to fill this gap by analyzing the impacts of some contextual factors on the entrepreneurial objective of college students.

Souitaris, V., Zerbinati, S., \& Al-Laham, A. (2007) Drawing on the theory of planned behavior, this research checks the outcome of entrepreneurship programs on business attitudes as well as intents of scientific research study and design students. This is needed in order to confirm (or disconfirm) basic knowledge that entrepreneurship education and learning increase the purpose to start a firm. The outcomes disclose that the programs boost some perspectives and the basic entrepreneurial intent which inspiration (a construct with an emotional aspect) is the programs' most significant advantage. The findings add to the ideas of ready actions and education and learning and additionally have bigger implications for a theory of service feelings in addition to in addition for the technique of training entrepreneurship.

\section{Research Methodology}

Present study is exploratory cum descriptive analysis in nature. The sample size is 400 respondents. Data were collected from the selective colleges (PG Diploma Students) from Chennai city. PG Diploma courses are Information Technology, Human Resource Management, Marketing, Systems, and other technical diploma courses. Respondents' participation was voluntarily \& completely anonymous. Only those PG Diploma students are consulted who are pursuing their course \& doesn't include those students who have passed out.

\section{Objectives of the study}

a. To analyze the factors influencing the students attitude towards entrepreneurship among PG Diploma students

b. To study and analysis of students intentions among PG Diploma students

c. To evaluate the opinion level about the factors that led to the emergence of entrepreneurs in outlook period

d. To study and evaluate students intentions to influence their new business processing ideas

\section{Limitations of the Study}


The study is micro level and limited to PG Diploma courses with different specialization of Chennai colleges, Tamilnadu. This study is conducted bearing in mind the sample size of four hundred students. The management, engineering and technical PG diploma pursuing students of Chennai engineering and other private institutions who are executing the PG Diploma courses around in Chennai City. The respondents which may not rationalize the survey as the view of students of other educational institute may differ. Because of bias and opinions of respondents, some responses of the questionnaire may differ from the reality.

\section{Data Analysis and Interpretation}

Table 4.1 Gender of the respondents

\begin{tabular}{|l|l|l|l|}
\hline S. No & Gender & Frequency & Percentage \\
\hline 1 & Male & 312 & 78.00 \\
\hline 2 & Female & 88 & 22.00 \\
\hline & Total & 400 & 100.0 \\
\hline
\end{tabular}

From the above table $4.1,78 \%$ of the respondents were male and remaining $22 \%$ of them were female. Majority $78 \%$ of the respondents were male.

Table 4.2 Age of the respondents

\begin{tabular}{|l|l|l|l|}
\hline S. No & Age & Frequency & Percentage \\
\hline 1 & Below 25 & 143 & 35.75 \\
\hline 2 & $26-29$ & 160 & 40.00 \\
\hline 3 & Above 30 & 97 & 24.25 \\
\hline 4 & Total & 400 & 100.00 \\
\hline
\end{tabular}

From the above table 4.2, the majority of the students were age group of 26-29 followed by $35.75 \%$ of students were below 25 and $24.25 \%$ of the respondents are in above 30 years.
Table 4.3 Previous Educational Qualification of the respondents

\begin{tabular}{|l|l|l|l|}
\hline S. No & $\begin{array}{l}\text { Educational } \\
\text { Qualification }\end{array}$ & Frequency & Percentage \\
\hline 1 & UG Degree & 140 & 35.00 \\
\hline 2 & PG Degree & 112 & 28.00 \\
\hline 3 & $\begin{array}{l}\text { Diploma }+ \\
\text { UG } \\
\text { Degree }\end{array}$ & 17 & 4.25 \\
\hline 4 & $\begin{array}{l}\text { Dual UG } \\
\text { Degree }\end{array}$ & 35 & 8.75 \\
\hline 5 & $\begin{array}{l}\text { Engineering } \\
\text { Degree }\end{array}$ & 96 & 24.00 \\
\hline & Total & 400 & 100 \\
\hline
\end{tabular}

From the above table 4.3, the majority of the previous educational qualification $35 \%$ students are in UG degree category followed by $28 \%$ students mentioned PG degree, 24\% respondents mentioned engineering degree and $8.75 \%$ are in dual UG degree category followed by $4.25 \%$ students mentioned diploma $+\mathrm{UG}$ degree category.

Table 4.4 Current Course of the respondents

\begin{tabular}{|l|l|l|l|}
\hline $\begin{array}{l}\text { S. } \\
\text { No }\end{array}$ & Educational Qualification & Frequency & Percentage \\
\hline 1 & PG diploma in HRM & 132 & 33.00 \\
\hline 2 & $\begin{array}{l}\text { PG Diploma in } \\
\text { Information } \\
\text { Technology }\end{array}$ & 76 & 19.00 \\
\hline 3 & PG Diploma in Marketing & 120 & 30.00 \\
\hline 4 & $\begin{array}{l}\text { PG Diploma in Project } \\
\text { Management }\end{array}$ & 55 & 13.75 \\
\hline 5 & $\begin{array}{l}\text { PG Diploma in Civil } \\
\text { Engineering }\end{array}$ & 17 & 4.25 \\
\hline & Total & 400 & 100 \\
\hline
\end{tabular}

From the above table 4.4, the majority of the current course of the students, $33 \%$ of the respondents mentioned PG Diploma in HRM and followed by $30 \%$ of the students mentioned in PG Diploma in 
Marketing, $19 \%$ of the respondents mentioned their current course is PG Diploma in Information Technology and followed by $13.75 \%$ students are in PG Diploma in Project Management, and 4.25\% are currently studying in PG Diploma in Civil Engineering degree course.

Table 5.5 How interested are you in

\begin{tabular}{|l|l|l|l|}
\hline $\begin{array}{l}\text { S. } \\
\text { No }\end{array}$ & $\begin{array}{l}\text { Response of } \\
\text { the students }\end{array}$ & Frequency & Percentage \\
\hline 1 & $\begin{array}{l}\text { 1-Very much } \\
\text { uninterested }\end{array}$ & 18 & 4.50 \\
\hline 2 & $\begin{array}{l}\text { 2- } \\
\text { Uninterested }\end{array}$ & 39 & 9.75 \\
\hline 3 & 3-Neutral & 53 & 13.25 \\
\hline 4 & 4-Interested & 164 & 41.00 \\
\hline 5 & $\begin{array}{l}\text { 5-Very much } \\
\text { interested }\end{array}$ & 126 & 31.50 \\
\hline & Total & 400 & 100 \\
\hline
\end{tabular}

From the above table 4.5, How interested are you in setting your own business immediately after your PG Diploma Course ,the majority of the students are mentioned "Interested" followed by $31.50 \%$ students are respondents are mentioned "very much interested", $13.25 \%$ students are mentioned "Neutral", 9.75\% students are mentioned "uninterested" and $4.50 \%$ are mentioned "very much uninterested"

\section{Findings and Suggestions}

a. From the above table $4.1,78 \%$ of the respondents were male and remaining $22 \%$ of them were female. Majority $78 \%$ of the respondents were male.

b. From the above table 4.2 , the majority of the students were age group of 26-29 followed by $35.75 \%$ of students were below 25 and $24.25 \%$ of the respondents are in above 30 years. c. From the above table 4.3, the majority of the previous educational qualification $35 \%$ students are in UG degree category followed by $28 \%$ students mentioned PG degree, $24 \%$ respondents mentioned engineering degree and $8.75 \%$ are in dual UG degree category followed by $4.25 \%$ students mentioned diploma + UG degree category

d. From the above table 4.4, the majority of the current course of the students, $33 \%$ of the respondents mentioned PG Diploma in HRM and followed by $30 \%$ of the students mentioned in PG Diploma in Marketing, 19\% of the respondents mentioned their current course is PG Diploma in Information Technology and followed by $13.75 \%$ students are in PG Diploma in Project Management, and $4.25 \%$ are currently studying in PG Diploma in Civil Engineering degree course.

e. From the above table 4.5, How interested are you in setting your own business immediately after your PG Diploma Course, the majority of the students are mentioned "Interested" followed by $31.50 \%$ students are respondents are mentioned "very much interested", $13.25 \%$ students are mentioned "Neutral", 9.75\% students are mentioned "uninterested" and $4.50 \%$ are mentioned "very much uninterested"

\section{Suggestions}

Business culture is common amongst PG diploma students. The Government, business assistances developers ought to take action to encourage the trainees in the production market with high originality. 
The trainees prepare to face the difficulties related to entrepreneurship, have a positive perspective towards entrepreneurship due to the regulations in between self- employment as well as formal employment many of them are not ready to take entrepreneurship as their professional choice. The study recommended that the pupils require to be given updates through entrepreneurial workshops and meetings in different fields to establish brand-new

ventures in the future. The Federal government has to extend more support in diverse locations to entrepreneurial tasks. The research recommended that the pupils require to be given updates through business workshops and conferences in different fields to establish the new venture in the future. Advertising an entrepreneurial society amongst youths. Supplying finance to pupils for state up brand-new ventures after leaving PG diploma degree courses.

\section{Conclusion}

This study is focus entrepreneurship attitude and entrepreneurship intention among PG Diploma students. A large part of students are interested in this area. Difficulties that have a possibility of influencing the motivation of PG Diploma students to take part in entrepreneurship activities after completing institution include accessing venture capital as well as an absence of business possibilities. The setting of raising fund is very vital in creation of new venture. The education and learning system is additionally affected by entrepreneurship in students. Several barriers are also affected by the production of the new endeavor. Accessibility of resources \& labor, family member's history, culture, corruption as well as govt plans are also affected in new endeavor development. Hence one can be wrapped up that the student's mindset in the direction of entrepreneurship is excellent. But some troubles are influenced to their for launch new endeavor creation. So the federal government, as well as worried authorities, takes remedial actions to address this problem.

\section{References}

[1] Bosma, N., \& Schutjens, V. (2011). Understanding regional variation in entrepreneurial activity and entrepreneurial attitude in Europe. The Annals of regional science, 47(3), 711- 742.

[2] Beugelsdijk, S., \& Noorderhaven, N. (2004). Entrepreneurial attitude and economic growth: A cross-section of 54 regions. The Annals of Regional Science, 38(2), 199-218.

[3] Chen, Y. F., \& Lai, M. C. (2010). Factors influencing the entrepreneurial attitude of Taiwanese tertiary-level business students. Social Behavior and Personality: an international journal, 38(1), 1-12.

[4] Turker, D., \& Selcuk, S. S. (2009). Which factors affect entrepreneurial intention of university students?. Journal of European industrial training.

[5] Souitaris, V., Zerbinati, S., \& Al-Laham, A. (2007). Do entrepreneurship programmes raise entrepreneurial intention of science and engineering students? The effect of learning, inspiration and resources. Journal of Business venturing, 22(4), 566-591.

[6] Díaz-García, M. C., \& Jiménez-Moreno, J. (2010). Entrepreneurial intention: the role of gender. International entrepreneurship and management journal, 6(3), 261-283. 
[7] Kristiansen, S., \& Indarti, N. (2004). Entrepreneurial intention among Indonesian and Norwegian students. Journal of Enterprising Culture, 12(01), 55-78.

[8] Krueger Jr, N. F., Reilly, M. D., \& Carsrud, A. L. (2000). Competing models of entrepreneurial intentions. Journal of business venturing, 15(5-6), 411-432.

[9] Zampetakis, L. A., Kafetsios, K., Bouranta, N., Dewett, T., \& Moustakis, V. S. (2009). On the relationship between emotional intelligence and entrepreneurial attitudes and intentions. International Journal of Entrepreneurial Behavior \& Research.

[10] Bucar, B., Glas, M., \& Hisrich, R. D. (2003). Ethics and entrepreneurs: An international comparative study. Journal of Business Venturing, 18(2), 261-281.

[11] Nabi, G., Holden, R., Harris, M. L., \& Gibson, S. G. (2008). Examining the entrepreneurial attitudes of US business students. Education + Training.

[12] Bosma, N., \& Schutjens, V. (2009). Mapping entrepreneurial activity and entrepreneurial attitudes in European regions. International Journal of Entrepreneurship and Small Business, 7(2), 191.

[13] Trevelyan, R. (2009). Entrepreneurial attitudes and action in new venture development. The International Journal of Entrepreneurship and Innovation, 10(1), 21-32. 